\title{
THE DISTRIBUTION AND ABUNDANCE OF THREE FISH SPECIES IN RELATION TO TIMBER DEBRIS AND MESO- HABITATS IN A LOWLAND FOREST STREAM DURING AUTUMN AND WINTER
}

\author{
T. E. Langford \& S. J. Hawkins \\ Centre for Environmental Sciences, University of Southampton, Highfield, Southamptori, Hampshire SO17 1BJ England
}

Keywords: Fish communities, wood debris, habitats, strearns

\section{SUMMARY}

In an autumn-winter study of the fish communities of a lowland forest stream Kruskal-Wallis one way analysis of variance has shown significant differences $(\mathrm{p}<0.05)$ in the catch densities, catch-weights per $\mathrm{m}^{2}$ and rnean individual weights of Salmo trutta, Cottus gobio and Phoxinus phoxinus from riffles, pools without wood debris and pools with timber debris accumulations.

Further analysis showed that the mean catch densities of $S$. trutta were significantly higher in pools with wood debric than in pools without wood debris. Catch weights and individual weights of trout were higher in the woody debris habitat than in pools without woody debris or riffles. In contrast, mean densities and catch weights of $C$. gobio were significantly higher in riffles than in the other two habitats but there was no significant difference between pools with and without wood debris. The rnean individual weights of $C$. gobio were also lower in the riffle habitats. Very few P. phoxinus were caught in riffles and there was no significant difference in densities between pools with and without wood debris. Catch weights and mean individual weights of $P$. phoxinus were highest in the pools with woody debris than in the other two habitats.

Length-frequency distributions showed that very few larger $S$. trutta were caught in the rifflec and there were relatively few small fish caught in the timber debris. The heterogeneity of depth and substrates in the pools and timber debris habitats is the main reason for the very wide size ranges of trout present. The distribution of smaller individualc of $S$. trutta on the riffles reduces their probability of predation by larger trout. The mean individual weights of both C. gobio and P. phoxinus show wide ranges in both pools with and without timber debris though the larger fish tend to be dominant in these habitats.

Evidence so far indicates that where debris dams cause ponding and increased sedimentation on riffles these areas of habitat would not be usable by young $S$. trutta and for all ages of $C$. gobio. In contrast the timber will increase the available refugia for older individuals of S. trutta, C. gobio and P.phoxinus.

This study is a preliminary part of a continuing long-terrn research programme on the significance of timber debris to fish in streams in Britain.

\section{INTRODUCTION}

The importance of timber debris, particularly coarse woody debris (CWD) to stream processes, water retention, the retention of organic material and sediments and to the ecology of the flora and fauna has been well documented for several regions of the world particularly North America and Australia (e. g., HARMON et al., 1986; BISSON et al., 1987; O'CONNOR, 1992; DOLLOFF, 1994; BRYANT \& SEDELL, 1995). The particular importance of woody debris to fich is discussed at length by

Limnetica, 13 (2): 93-102(1997)

I. Pozo \& A Elosegi (eds)

Proceedings of thr European Meeting on Liter Breakdown in Rivers and Streams (C) Asociación Española de Limnología, Madrid, Spain.
BISSON et al. (1987).

In Britain, most of the research on timber debris has concentrated on the geomorphological and hydrological significance of debris dams, mostly in the New Forest in southern England (GURNELL \& GREGORY, 1984; GREGORY et al., 1985: GREGORY 1992: GREGORY \& DAVIS, 1992; GREGORY et al., 1993; GURNELL et al., 1995; EVERETT, 1997). To date, there has been no published research on the macro-biological aspects of tirnber debris streams in British stream systems.

Decpite the numerous studies in New Forest streams, there 
are different viewpoints on the ecological and economic value of debris dams in these lowland streams, mainly because of the differing requirements of Forest users (LANGFORD, 1996). For example commercial forestry and the grazing of animals requires well drained soils and rapid water removal while anglers require that migratory fish have clear passage to and from spawning reaches. Both viewpoints consider that debris dams may be detrimental to these requirements, though anglers accept that wood debris can provide refugia for fish (LAPPIN, pers. comm.). On the other hand conservationists require natural and complex habitat structures in streams for the maintenance of ecological diversity. This complexity is partly provided by debris dams and wood debris accumulations within the stream systems (BISSON et al., 1987).

The present studies began in response to the lack of direct biological data relating to timber debris in British streams and from the New Forest in particular. The objective of the research programme is to quantify the role of timber debris in the ecological structure of the streams, particularly in relation to the communities of fish and invertebrates and to provide data on which the future management of forest stream systems can be based. This paper describes a preliminary analysis of data from the early part of continuing studies on the fish community and relates to the autumn and winter of 1996 and 1997. The distribution, abundance and size segregation of three species of fish in timber debris are compared with those in riffles and pools without timber debris.

\section{DESCRIPTION OF THE SITE}

The New Forest in southern England is a unique area of Britain and its history and development are well described by TUBBS (1968, 1986). It was created as a hunting forest during the late 11th century and through a complex sociological and ecological evolution has become one of the most important conservation areas in northern Europe. Much of the Forest is a British Site of Special Scientific Interest (SSSI) and is protected by the European Habitats Directive. It is also a RAMSAR site and has the highest grade listing as a British conservation area. The total area is about $38 \times 10^{3}$ ha. The main terrestrial habitats are lowland heath, valley mire, ancient pasture woodland, all of which are "rare and fragmented" in northern Europe (TUBBS, 1986), together with oak and beech forest, interspersed with commercial conifer plantations. This mosaic of habitats supports a diverse flora and fauna. The underlying rocks are mostly sedimentary clays, topped with gravels. The soils are mainly poor and acidic though they become richer toward the fringes of the area.
The drainage system compnses a number of catchments containing short streams, none over $30 \mathrm{~km}$ long and all having their sources within the Forest boundary (fig. 1). The highest source is at $128 \mathrm{~m}$ above Ordnance Datum (OD). Stream widths range from $0.3 \mathrm{~m}$ to $7 \mathrm{~m}$, gradients are mainly less than $1.0 \%$ and current velocities rarely exceed $0.5 \mathrm{~m} \mathrm{~s}^{-1}$ (LANGFORD, 1996). The flows are typically low but rise and fall rapidly after heavy rain. The soft stream banks are often deeply undercut. Tree roots and trailing grasses form the main marginal vegetation. In-stream vegetation is relatively sparse except where there are large openings in the forest canopy and in the lower reaches of the systems where the marginal lands are cultivated. The published data on the ecology of the streams is reviewed by LANGFORD (1996).

Timber debris is widespread in the streams (GREGORY et al., 1993), with densities ranging from sparsely scattered submerged branches and logs on the stream bed to full-scale dams consisting of large logs and trees with smaller twigs and leaves packed into the interstices. The sampling sites from which the data in this paper originate are within $\mathbf{a} 4 \mathbf{k m}$ reach of the Highland Water, a main feeder stream of the Lymington River. This reach lies within and downstream of the New Forest research catchment as shown on fig. 1 .

The channel of the Highland Water in its middle and upper reaches varies typically in width from approximately $2 \mathrm{~m}$ to 5 $\mathrm{m}$. In a few reaches the stream narrows to a wetted width of 1

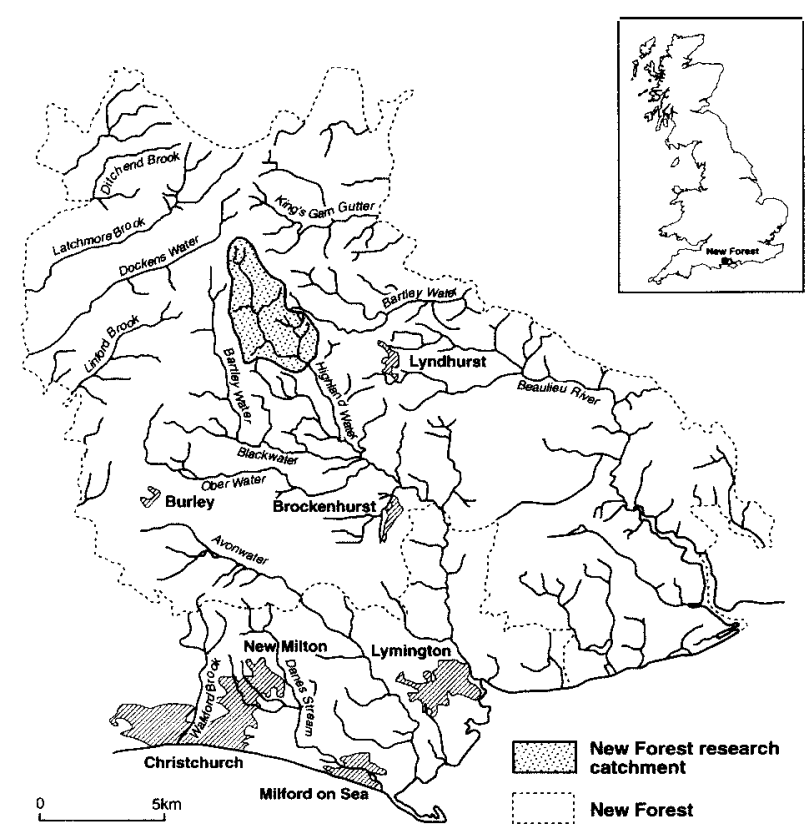

Figure 1. The drainage aystem of the New Forest, Hampshire, southern England. 
$\mathrm{m}$ or less and where tree debris has caused bank erosion the water width can reach up to $5.5 \mathrm{~m}$. The nver is some $25 \mathrm{~km}$ long with a total fall of $150 \mathrm{~m}$ from its source to the sea. Gradients are low and the substrates mostly sand and gravels. In the upper reaches the substrate contains cobbles of up to 12 $\mathrm{cm}$. There are no emergent rocks, boulders or exposed areas of bedrock. The typical structure of the channel in a sample reach and its instream substrates is shown in fig. 2.

\section{METHODS}

Samples of fish were taken from selected sites at monthly intervals from September 1996 to January 1997. Each sampling site chosen was centred on a timber debris accumulation. Fig. 3 shows a typical site in diagrammatic form. At each site, contiguous habitat sections upstream and downstream of the debris accumulation were identified and separated off for sampling using stop-nets with a mesh size of $1 \mathrm{~cm}$. The debris dam or pile was also isolated using the same type of net (fig. 3). To
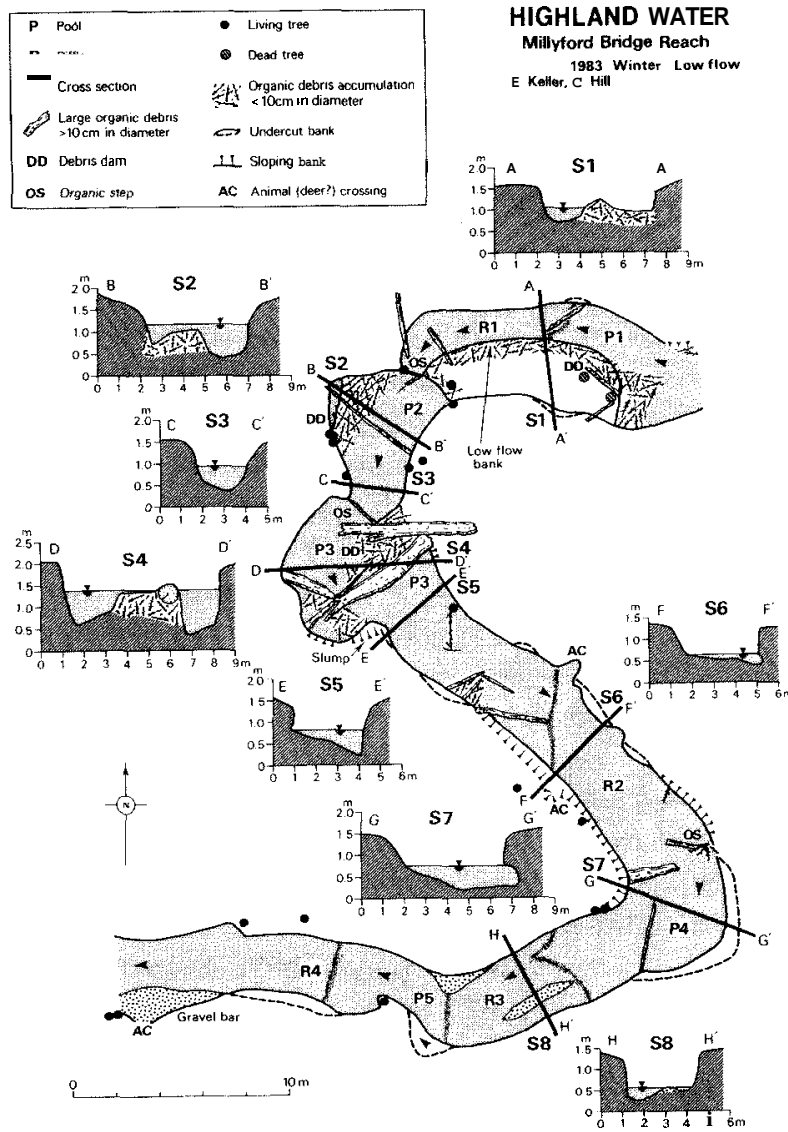

Figure 2. Plan view of a typical reach of the Highland Water showing timber debris and instream substrates (reproduced with permission).

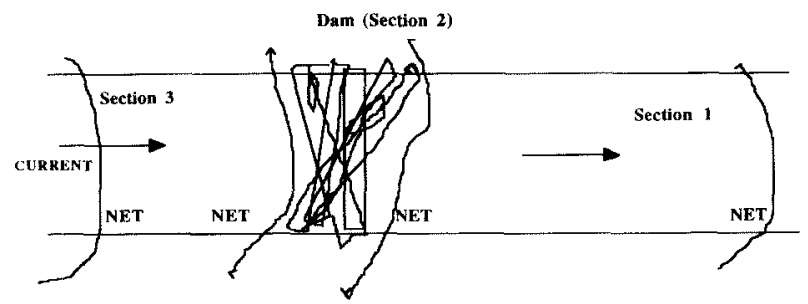

Figure 3. Schematic layout of sampling sections in relation to a debris dam at a typical site in a New Forest stream.

enclose the dam, the nets were laid as close to the upstream and downstream extremities of the timber accumulation as possible. For this preliminary analysis no attempt has been made to assess the amounts of timber at each site though each was either a full-width dam, partial dam or a marginal pile.

Each site typically comprised three or four contiguous sections, (fig. 3) for example a section upstream of the timber debris accumulation, the dam or pile itself and a section downstream. Each section chosen was usually an identifiable ( $\boldsymbol{a}$ priori) stream meso-habitat unit for example, riffle, pool-glide or wood debris accumulation. The sections varied in length at each site from a minimum of $3 \mathrm{~m}$ to a maximum of $25 \mathrm{~m}$ depending on the length of the identifiable habitat unit. Nine different sites were sampled which included ten sections with timber debris. Two sites were sampled twice in the sampling period. Although there was considerable physical variation from site to site, they and their sections (table 1) can be regarded as replicates for the purposes of this study. Details of individual sites and sections will be given in subsequent accounts (LANGFORD, in preparation).

The sections classified as pools also included stretches of slow-glides in which the current was visually detectable in the upstream parts but became undetectable as the debris dam or pile was approached. These slow glides and the shallower margins of the channel account for much of the variation in depths

Table 1. Dimensions of sections (meso-habitat types) in New Forest streams used for comparisons of fish populations (September 1996 to January 1997).

\begin{tabular}{lccc}
\hline & Riffles & Pools & Debris \\
Number of replicate sections & 9 & 25 & 14 \\
Mean depth (highest) (cm) & 16 & 61 & 95 \\
Mean depth (lowest) (cm) & 1 & 17 & 13 \\
Max. SD of depth (any section) & 9 & 436 & 389 \\
Min. SD of depth (any section) & 0.5 & 7 & 5 \\
Max. width (m) & 6 & 6.5 & 5.1 \\
Min. width (m) & 1.3 & 1.9 & 1.13 \\
Max. length (m) & 5.1 & 25.6 & 5.3 \\
Min. length (m) & 10.3 & 3.4 & 3
\end{tabular}


Table 2. Primary and secondary substrates in three meso-habitat types in New Forest streams.

\begin{tabular}{|c|c|c|}
\hline Habitat type & Primary substrata & Secondary substrata \\
\hline Riffles & gravei, small cobbies & $\begin{array}{l}\text { ieaves, clay, sand, roots, } \\
\text { wood }\end{array}$ \\
\hline Pools (without wood) & gravel, siit, leaves & $\begin{array}{l}\text { ciay, silt, sand, ieaves, } \\
\text { trailing, grasses, roots }\end{array}$ \\
\hline $\begin{array}{l}\text { Debris dams/pools } \\
\text { with wood }\end{array}$ & $\begin{array}{l}\operatorname{logs}, \text { branches, } \\
\text { leaves }\end{array}$ & silt, clay, gravel \\
\hline
\end{tabular}

in these sections (table 1). There was also a wider range of substrates in the pools and timber debris sites than in the riffles, reflecting the variations in depth and currents. Riffle sections were typically more uniform in both depth and substrate composition (tables 1,2).

The areas of water surface enclosed by the nets and the banks were estimated using a series of width and bank length measurements. At some sites submerged timber made it difficult to enclose the section fully though gaps were usually small and there were few instances where the original location of the fish caught was in doubt.

Once the sections were enclosed, each was sampled using a 240 volt, smooth DC Aquatic Services International electric fishing machine. The classic serial-depletion method was used for sampling the fish community (see MAHON, 1980). A minimum of three sampling runs was made and all fish collected on each run were kept in separate containers. For this paper the total catch in the three runs at each site is used for compansons of abundance, expressed as numbers of fish and weight of fish per unit area of water surface $\left(\mathrm{m}^{2}\right)$ (SEBER \& LE CREN, 1967; MAHON, 1980). The relationship between catch data and population estimates for all species is addressed in subsequent papers (LANGFORD, unpublished data). All fish were weighed and measured on the stream bank except minnows (Phoxinusphoxinus) all of which were collected and taken to the laboratory for specific studies. To reduce effects of destructive sampling most fish except minnows were returned to the reach from which they were caught.

The data from the fish sampling in each stream section were used to estimate mean catch density (total number of each species caught/water surface area in the section), mean catch weight (total weight of each species caught/water surface area in the section expressed as $\mathrm{g} \mathrm{m}^{-2}$ ) and mean individual weight (total weight of each species caughtítotal number caught in the section).

The sections sampled over the whole period were uced as replicates for the statistical analysis. Abundance and size data varied in their frequency distributions from normally to nor- mally distributed. Following trial analyses using parametric one-way analysis of variance (ANOVA) on both transformed data $\left(\log _{10} x+1\right)$ and non-transformed data in addition to nonparametric tests (ELLIOTT, 1977), the results of the KruskalWallis one-way analysis of variance were used to indicate the significance of differences between habitats. In addition groups of data from pairs of habitats were analysed using the MannWhitney $\mathbf{U}$ test (see ELLIOTT, 1977).

\section{RESULTS}

The species collected in the total sampling programme were sea-trout and brown trout, (Salmo trutta Linnaeus 1758), bullheads, (Cottus gobio, Linnaeus 1758), minnows, (Phoxinus phoxinus (Linnaeus 1758)), stone loach (Noemacheilus barbatulus (Linnaeus 1758)) and eels (Anguilla anguilla (Linnaeus 1758)) In addition specimens of Petromyzonidae species were collected of which adults of Lampetra planeri (Bloch, 1784) have been identified most commonly. Ammocoetes of L. fluviatilis (Linnaeus 1758) are believed to be present in some samples though these have yet to be positively identified. No other species were recorded in this reach, though other species are known to occur downstream (LANGFORD, 1996). For this paper, trout and sea-trout are treated as a single taxon though from preliminary observations it is clear that the majority of salmonids caught over 1 year old were sea-trout parr, smolts or adults.

Salmonids comprised $12 \%$ of the total numbers of fish caught in riffles, $14 \%$ in pools without debris and $19 \%$ in pools with timber debris. The respective proportions by weight were $22 \%, 48 \%$ and $38 \%$. Cottids comprised $32 \%, 4 \%$ and $1 \%$ by numbers respectively in riffles pools and timber debris and $84 \%, 16 \%$ and $7 \%$ by weight. The proportions of Phoxinus were respectively $2 \%, 48 \%$ and $60 \%$ by numbers and $1 \%, 14 \%$ and $5 \%$ by weight. Cottids were therefore numerically dominant in riffles, while $P$. phoxinus was numerically dominant in the two other meso-habitats.

The mean catch densities of $S$. trutta were highest in the timber debris sections with 0.27 fish $\mathrm{m}^{-2}$ (fig. 4a), but the differences between the means for riffles and pools and riffles and debris sections were not significant (tables 3, 4). Differences between pools and debris sections were significant (table 4) despite the wide range of densities recorded. In contrast catch densities for $C$. gobio were significantly greater in the riffles (tables 3,4 ) with about 0.85 fish $\mathrm{m}^{-2}$ (fig. 4b). The differences between the meanc for pools and timber debris were not significant, (table 4). The data for P. phoxinus show a similar trend to those for S. trutta (fig. 4c) with higher densities and wider ranges in pools and debris sections. The differences between pools 


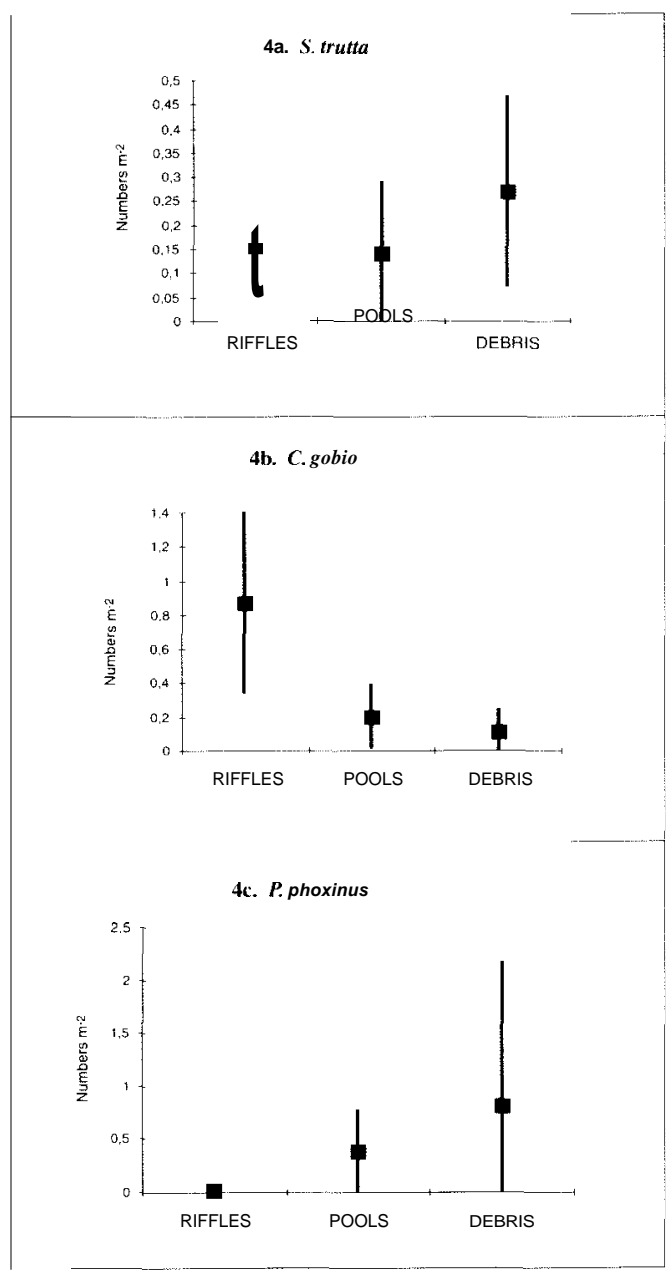

Figure 4. Mean and standard deviations of catch densities of three species of fish in three meso-habitats in New Forest streams.

Table 3. Results of Kruskal-Wallis one-way analysis for differences bet ween mean catch densities, catch weights and individual weights for fist from three meso-habitat types in New Forest streams.

\begin{tabular}{cccc}
\hline Measurement & Value of H & $\begin{array}{c}\text { Degrees } \\
\text { of freedom }\end{array}$ & $\begin{array}{c}\mathbf{P} \\
\text { (less than) }\end{array}$ \\
S. trutta (densities) & 5.87 & 2 & $.10(\mathrm{NS})$ \\
(wt. m ${ }^{-2}$ ) & 12.67 & 2 & $.01^{* *}$ \\
(ind. wt) & 12.64 & 2 & $.01^{* *}$ \\
C. gobio (densities) & 16.98 & 2 & $.001^{* * *}$ \\
(wt. m ${ }^{-2}$ ) & 12.27 & 2 & $.01_{* *}^{*}$ \\
(ind. wt) & 9.20 & 2 & $.05^{*}$ \\
P. phoxinus (densities) & 16.44 & 2 & $.001^{* * *}$ \\
(wt. m ${ }^{-2}$ ) & 17.82 & 2 & $.001^{* * *}$ \\
(ind. wt) & 4.62 & 2 & $.3(\mathrm{NS})$ \\
\hline
\end{tabular}

$\mathrm{NS}=$ Not significant, $*$ significant, **very significant

**** highly significant

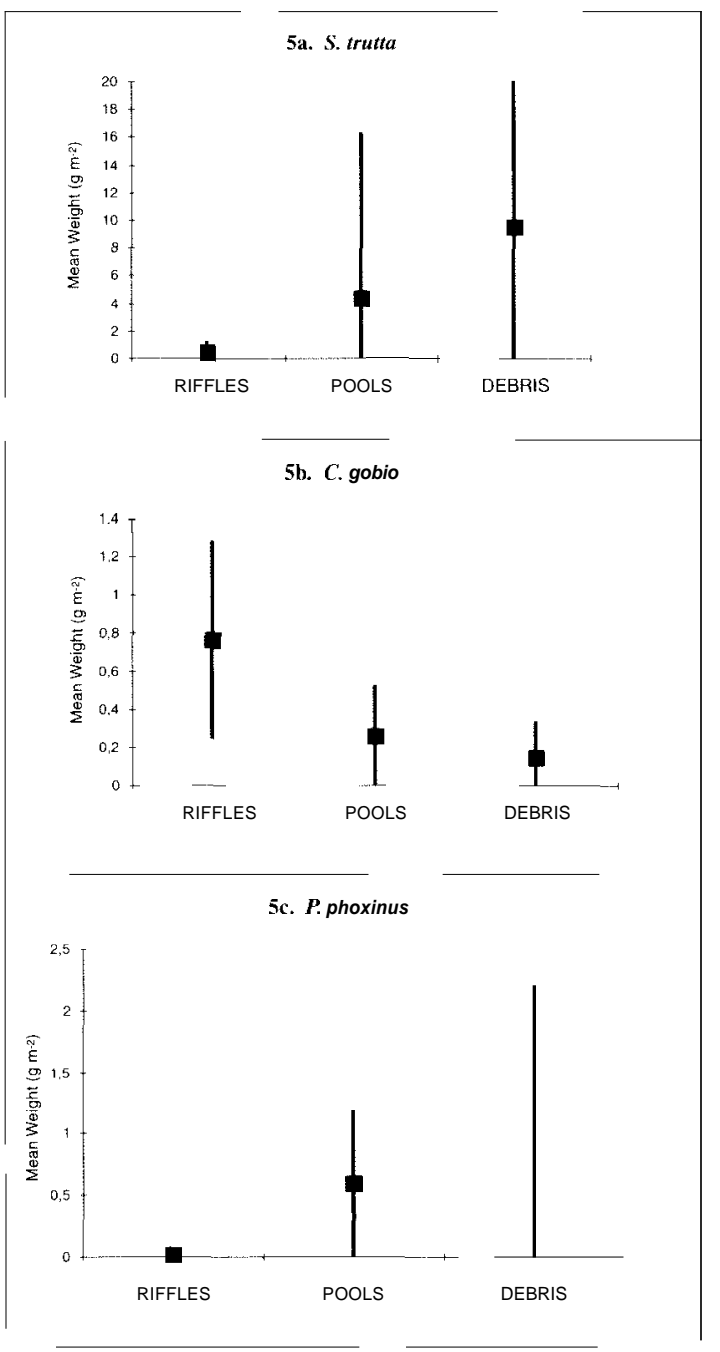

Figure 5. Means and standard deviations of total catch weights of three species of fish in three meso-habitat types in New Forest streams $\left(\mathrm{g} \mathrm{m}^{-2}\right)$.

Table 4. Resulta of Mann-Whitney $\mathbf{U}$ tests for the significance of differences between catch densities (numbers $\mathrm{m}^{-2}$ ) for three species from three meso-habitat types in New Foreat streams (figures are caiculated values of $\mathrm{p}$ ).

\begin{tabular}{ccc}
\hline Salmo trutta & Pools & Debris \\
Riffles & $0.76(\mathrm{NS})$ & $0.065(\mathrm{NS})$ \\
Debris & $0.028\left({ }^{*}\right)$ & \\
Cottus gobio & & \\
Riffles & $0.0006(* *)$ & $0.0005(* *)$ \\
Debris & $0.0526(\mathrm{NS})$ & \\
Phoxinusphoxinus & & \\
Riffles & $0.0002(* *)$ & $0.0009(* *)$ \\
Debris & $0.115(\mathrm{NS})$ & \\
\hline
\end{tabular}




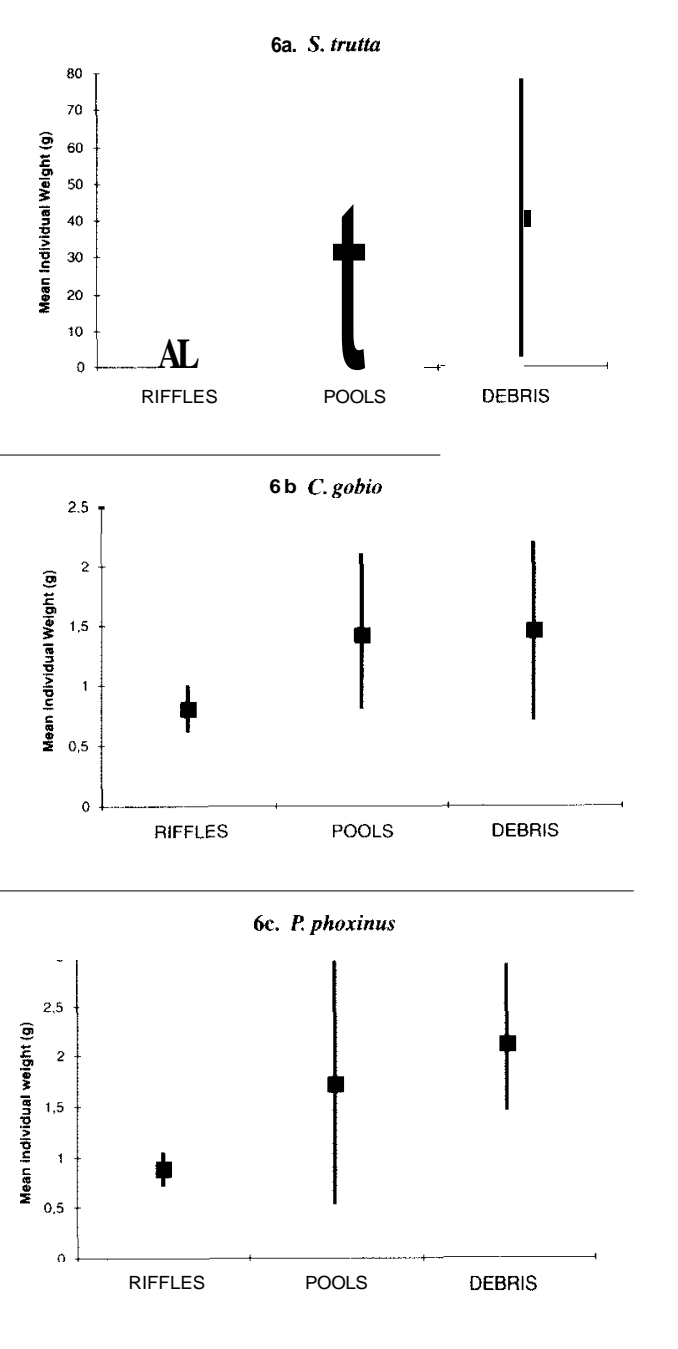

Figure 6. Means and standard deviations of mean individual weights of three species of fish from three meso-habitat types in New Forest streams.

Table 5. Results of Mann-Whitney U tests for the significance of differences between catch weights per unit area $\left(\mathrm{g} \mathrm{m}^{-2}\right)$ for three species from three meso-habitat types in New Forest streams (figures are calculated values of $\mathrm{p}$ ).

\begin{tabular}{ccc}
\hline Salmo trutta & Pools & Debris \\
Riffles & $0.04\left({ }^{*}\right)$ & $0.007(* *)$ \\
Debris & $0.01\left(^{* *}\right)$ & \\
Cottus gobio & & \\
Riffles & $0.012\left(^{*}\right)$ & $0.002(* *)$ \\
Debris & $0.084(\mathrm{NS})$ & \\
Phoxinus phoxinus & & \\
Riffles & $0.0016\left(^{*}\right)$ & $0.0152\left(^{*}\right)$ \\
Debris & $0.0003(* *)$ & \\
\end{tabular}

Table 6. Results of Mann-Whitney U tests for the significance of differences between individual weights of fish caught from three mesohabitat types in New Forest streams (figures are calculated values of $p$ )

\begin{tabular}{ccc}
\hline Salmo trutta & Pools & Debris \\
Riffles & $0.02\left({ }^{*}\right)$ & $0.001(* * *)$ \\
Debris & $0.1(\mathrm{NS})$ & \\
Cottus gobio & & \\
Riffles & $0.0015(* *)$ & $0.084(\mathrm{NS})$ \\
Debris & $0.88(\mathrm{NS})$ & \\
Phoxinus phoxinus & & \\
Riffles & $0.002\left(^{* *}\right)$ & $0.002\left(^{* *}\right)$ \\
Debris & $0.29(\mathrm{NS})$ & \\
\end{tabular}

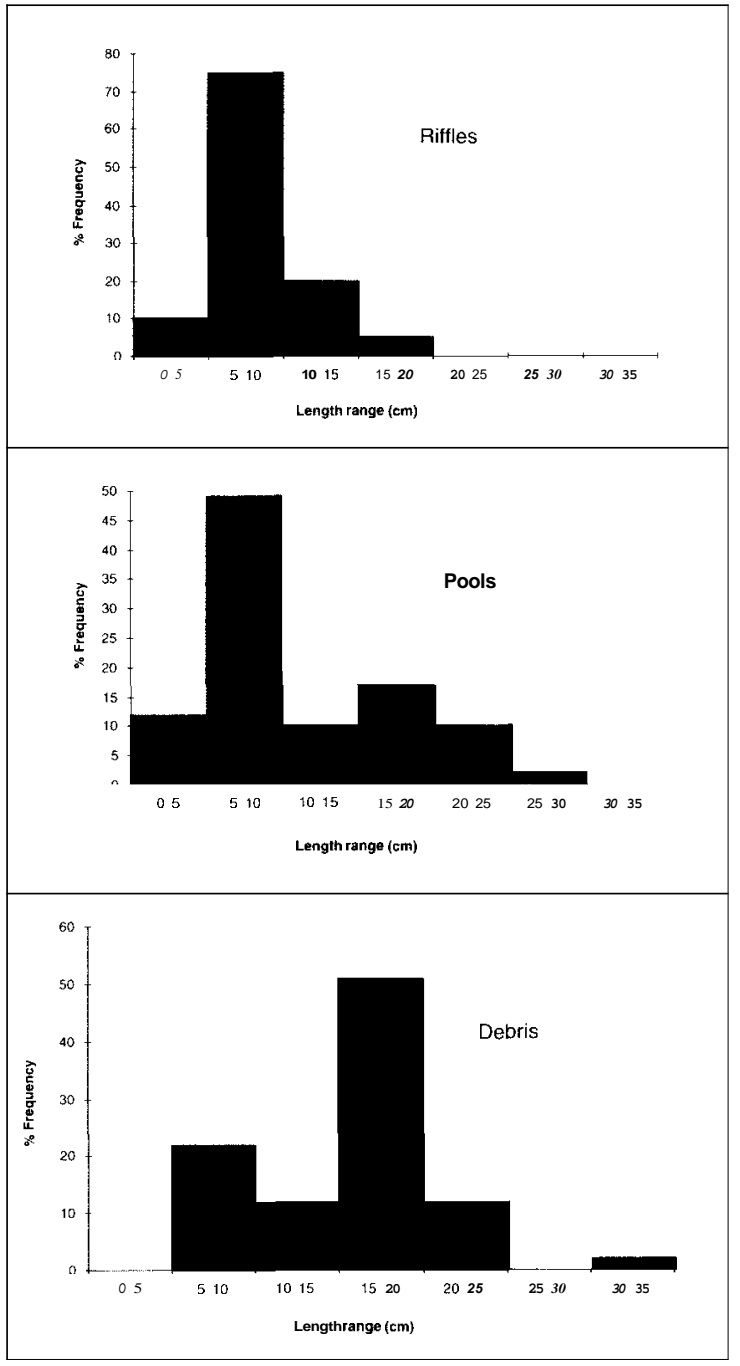

Figure 7. Percentage length - frequencies of trout (Salmo trutta) in three habitat types in New Forest streams (winter 1996-97). 
and debris sections were not significant (table 4).

The mean total catch weights of $S$. trutta were significantly higher in pools and debris sections (fig. 5a; tables 3,5) with both the highest mean weights and the widest range in the debris sections. P. phoxinus chowed the same trends (fig. 5c) but $C$. gobio showed the reverse trend (fig. $5 b$ ), with the highest mean total weights in the riffles. For this species the differences between mean total weights between pools and debris sections were not significant (table 5).

Analysis of the individual weights of the three species showed that both the mean individual weight and ranges for $S$. truttu, C. gobio and P.phoxinus were greater in the pools and timber debris sections than in the riffles (fig. 6a, b, c) but the differences between mean individual weights of fish from the pools without timber and those with timber debris were not significant for either species (tables 3,6).

The largest trout, a sea-trout, was caught in a debris section. Length-frequency distributions show that the proportion of large fish found in the debris habitats (fig. 7) was larger than in the pools without debris. The lower mean size of trout in the pools was clearly influenced by the higher proportion of smaller trout also caught in these habitats. Modal length ranges for trout in riffles and pools are $5-10 \mathrm{~cm}$ while the modal length range for trout from the debris sections was in the $15-20 \mathrm{~cm}$ (fig. 7).

\section{DISCUSSION}

There were clear and significant differences in both size distnbution and abundance arnong the three fish species in relation to timber debris and meso-habitat type at the sites studied though trout ( $S$. trutta) and bullheads ( $C$. gobio) show opposite trends in relation both to increasing depth and the presence of timber debris. The former were more abundant in pools and debris sections, the latter less abundant. Minnows, (1? phoxinus) show similar tendencies to the trout in terms of catch densities and weight caught. There were, however, large overlaps in the ranges of densities and weights of $S$. trutta caught in pools and debris habitats and the abundance and weights of species were not generally significantly different in these habitat types. Size related selection of pools and riffles by $S$. trutta is well documented but there are no data for timber debris (see MAITLAND \& CAMPBELL, 1992; ELLIOTT, 1994).

It is possible that the reasons for the differences in catches may be related to capture methods or the differential catchability of the species in the different habitats but at this stage in the work, there is no reason to believe that catchability differences between species and habitats have affected the results so far. Further studies will attempt to evaluate effects of catchability and the relative success of the depletion methods for species and meso-habitat types (MAHON,1980).

The data show clear differences between habitat types in mean catch densities, mean catch weights and individual weights of the three species of fish considered in this paper. The differences between the riffles and the deeper meso-habitats are most marked. There is also considerable variability in mean abundance and size within the habitat types, particularly for trout and minnows in pools and riffles and for bullheads in riffles.

The fact that there was an overlap both in the ranges of abundance and size distribution in all three species was most likely a function of the heterogeneity of depths and substrates within the habitat units particularly in pools and timber debris habitats. Even in the habitats classified as riffles, there were areas of deeper water and areas of other substrata than gravel or cobbles (tables 1,2 ), though riffles were typically more homogeneous than pools or tirnber debris habitats.

Both minnows and larger trout were more abundant in deeper water, though minnows are shoaling species and trout more territorial and solitary in these streams. In these deeper sections, irrespective of the presence of timber debris, the banks tend to have more cover either in the form of undercuts overhung with vegetation or with submerged tree roots. There are, therefore, a variety of refugia near the margins for the larger trout irrespective of the presence of timber debris. Some habitats classified as pools here also have small areas of gravel at the margins or at the head of a slow glide leading into a pool. These areas contain small trout of similar size ranges as found among gravels in the riffle areas. This variation in substrate and cover is likely to be the main reason for the higher proportion of smaller fish and the wider size range in pools than in the timber debris habitats. The timber debris, particularly where it reaches across the stream, clearly provides an extension to the marginal refugia.

C. gobio appears to be competing for space in shallow riffles with under yearling trout as indicated by densities and weights of both species in this habitat. The extent to which the species compete for food and space will be the subject of further work, though studies in other New Forest streams suggest that there is some overlap in the diets (MANN \& ORR, 1969). The relative scarcity of $C$. gobio among the timber debris is believed to be related to the depth of water and speed of currents in the reaches where timber accumulates. In riffles, C. gobio is often found under or in the shelter of single logs or branches in addition to its distribution among the gravel, but for this work rnost of the concentrated timber accumulations were in deeper slower water which the data here show is not a major habitat for the species. The reason for the selection of shallow habitats by smallest trout may be because of cannibalism among the species though this 
has yet to be verified. Preliminary observations indicate that cannibalism occurs in the Highland Water and in other streams (MANN \& ORR, 1969; LANGFORD, unpublished data).

In most of the published studies of the relationship between timber debris and fish, there has been some concentration on salmonids, particularly in upland streams (see BRYANT \& SEDELL, 1995). Typically, the sites chosen were in backwaters and cut-offs (off-channei habitats) from main river channels where timber accumulated and where the habitat consisted of both gravel and timber debris. As a general rule, the densities of salmonids were greater in these side channels and they were regarded as primary rearing areas for small fish. BRYANT (1985) showed that densities of coho salmon were 6-7 times greater in off-channel habitats in a stream where wood was present, though there was no direct relationship between amounts of large timber debris and fish densities. In the New Forest streams all the habitat units sampled were in the main stream though generally the streams are small and sampling was carried out at lower flow ranges. The increase in mean density was found to be a factor of 2 between riffles and debris sections, but the increase in mean weights per unit area was by a factor of up to 10 between riffles and pools and 20 between riffles and debris sections. The main reason was the size related habitat selection by trout, the large fish being found in the deeper and more heterogeneous habitats units. In other lowland streams with sand or silt substrates timber debris may form spawning or nesting sites for fish (e.g., JACKSON, 1978) or may be major refugia (ANGERMEIER \& KARR, 1984). In the New Forest streams, there is no evidence as yet for the use of timber debris as a spawning site though further studies may show otherwise. Both trout and bullheads spawn on the gravel riffles (MAITLAND \& CAMPBELL, 1992) but the location for minnow spawning has not yet been determined. It is believed to be among trailing vegetation and fine tree roots.

In a recent study of prairie streams which contain mostly non-salmonids, BRAATEN \& BERRY (1997) found that both riffles and woody habitats contained more young cyprinids than pools or runs during moderate discharges, but that in the periods of low discharges the highest densities were in the riffles. Larger individuals were relatively evenly distributed among the habitat types. They also found that none of the 16 speciec in their streams was consistently associated with a particular habitat, though medium sized and larger channel catfish (Ictalurus punctatus) were more common in riffles and woody habitats. There were also flow-related changes in the relative distribution of species among the habitat types. Clearly, the data show parallels to those from the Highland Water in that species are not restricted to particular habitat types, but show size rela- ted differences in their use.

Several authors have concluded that timber debris increases the total secondary production of many streams in the form of invertebrate biomass (BRYANT \& SEDELL, 1995; HARMON et al., 1986). This in turn has been shown to be utilised as a food resource for fish. In the New Forest streams, the use of the wood based invertebrates by fish has yet to be determined, but the indications are that for large trout, the timber is a major refuge, probably an extension of the natural marginal refuges, rather than a direct source of food. For bullheads and underyearling trout the presence of timber may in fact be detrimental to the popuiation if it causes increases in water depth and siltation of gravels. For the minnow population the depth of water and presence of marginal habitat may be the most important factor independent of the presence of timber debris.

\section{CONCLUSION}

Timber debris, particularly coarse woody debris, clearly allows increased densities and weights of trout per unit area of water surface in New Forest streams. The increase in refuge diversity for larger trout appears to be the main factor. 'At the same time, if a timber dam enhances the impoundment of water and results in an increase in siltation of gravel-based riffles it will be detrimental to both underyearling trout and to the population of bullheads (C. gobio), for whom shallow riffles are the main habitats. It will also lead to the siltation of spawning sites for salmonids and C. gobio. The presence of timber debris is less significant to minnows ( $P$. phoxinus). These clearly benefit from deeper water and probably from the increased marginal habitat diversity for larger individuals which is associated with this deeper water. The indication from this analysis of the early data is that for the trout, timber debris is a major refuge though mainly as an extension to the marginal refugia. The extent to which it provides a resource is not yet determined and will be the subject of the continuing project and future publications.

\section{ACKNOWLEDGEMENTS}

This paper was presented at the "European Meeting on Litter Breakdown in Rivers and Streams" organised by the University of the Basque Country, Bilbao in September 1997. The authors are grateful to the organisers for the opportunity to present the work and for some support for the conference. Thanks are due also to staff of the Environment Agency (Southem Region) for advice and assistance, to Fawley Aquatic Research Laboratories for the extended loan of electric fishing equipment, to the 
Linnaean Society. the Freshwater Biological Association, Engiish Nature and the Ficheries Society of the British Isles for supporting funds and to colleagues and students at the Centre for Environmental Sciences, University of Southampton for advice and assistance. Special thanks go to Jean Langford, Alison Graham-Smith and Simon Bray for their regular aiid continuing assistance in the fieid. We are grateful to the Forestry Commission (Forest Enterprisej for permission to work in the New Forest. Figure I wac adapted with the permission of Dr. David Sear ofthe University of Southainpton.

\section{REFERENCES.}

ANGERMEIER, P.L. \& J.R. KARR, 1984. Relationships between woody debris and fish habitat in a small warmwater stream. Trans. Am. Fish. Soc., 113: 716-726.

BISSON, P.A., R.E. BILBY, M.D. BRYANT, C.A. DOLLOFF, G.B. GRETTE, R.A. HOUSE, M. MURPHY, K.V. KOSKI \& J.R. SEDELL, 1987. Large woody debris in forested streams in the Pacific Northwest: past. present and future. In: Streamside management: Forestry and fishery interactions (E.O. SALO \& T.W. CUNDY, eds.): 143-190. Contribution No. 57. Institute of Forest Resources, University of Washington.

BRAATEN. P.J \& C.R. BERRY, 1997. Fish associations with four habitat types in a South Dakota prairie stream. $J$. Freshwat. Ecol, 12:477-489.

BRYANT, M.D.. 1985. Changes 30 years after logging in large woody debris. and its use by salmonids. In: Riparian ecosystems and their management: reconciling conflicting uses (R. JOHNSON, C.D. ZIEBELL, D.R. PATTON, P.F. FFOLLIOTT \& R.H. HAMRE, eds.): 329-334. USDA Forest Service General Technical Report RM-120, Fort Collins.

BRYANT, M.D. \& J.R. SEDELL, 1995. Riparian forest, wood in the water, and fish habitat complexity. In: The condition of major aquatic habitats, Theme I. (N.B. ARMAN TROUT, ed.): 202-204. Proceedings of the Worlds Fisheries Congress. Science Publishers, Athens.

DOLLOFF, C.A., 1994. Large woody debris: the common denominator for integrated environmental iiianagement of forest streams. In: Implementing integrated environmental management (J.Jr. CAIRNS, T.V. CRAWFORD, \& H. SALWASSER. eds.j: 93-108. Center for Environmental Management and Hazardous Materials Studies, Virginia Polytechnic Institute and State University, Blacksburg.

ELLIOTT. J.M., 1977. Some methods for the statistical analysis of samples of benthic invertebrates. 2 nd. ed. Scientific Publication No. 25. Freshwater Biological Association. Ambieside. ELLIOTT, J.M., 1994. Quantitative ecology and the brown trout. Oxford Series in Ecology and Evolution. Oxford University Press, Oxford.

EVERETT, S. (ed.), 1997. A review of the effects of woody debris on stream processes, flora and fauna with special reference to the New Forest. Report to the Environment Agency U.K. (Southern Region), Hampshire Wildlife Trust.

GREGORY, K.J., 1992. Vegetation and river channel process interactions. In: River Conservation and Management. (P.J. BOON. P. CALOW \& G.E. PETTS. eds.): 255-269. John Wiley $\&$ Sons, Chichester.

GREGORY, K.G. \& R.J. DAVIS, 1992. Coarse woody debris in stream channels in relation to river channel management in woodland areas. Reg. Riv.: Res. \& Man., 7: 117-136.

GREGORY, K.J., R.J. DAVIS \& S. TOOTH, 1993. Spatial dictribution of coarse woody dehris dams in the Lymington Basin. Hampshire, U.K. Geomorphology, 6: 207-224.

GREGORY, K.J., A.M. GURNELL \& C.T. HILL, 1985. The permanence of debris dams reiated to river channel processes. Hydrol. Sci. J., 30: 37 i -381.

GURNELL, A.M. \& K.J. GREGORY, 1984. The influence of vegetation on stream-channel processes. In: Field experiments in geomorphology (D.E. WALLING \& T.P. BURT. eds.): 515-535. Geobooks.

GURNELL, A.M., K.J. GREGORY \& G.E. PETTS, 1995 The role of coarse woody debris in forest aquatic habitats: implications for management. Aquatic Conservation: Marine and Freshwater Ecosystems, 5:143-166.

HARMON, M.E., J.F. FRANKLIN. F.J., SWANSON, P. SOLLINS, .S.V. GREGORY, J.D. LATTIN, N.H. ANDERSON, S.P. CLINE, N.G. AUMEN, J.R. SEDELL, G.W. LIENENKAEMPER, K. CROMACK \& K.W. CUMMINS, 1986. Ecology of coarse woody debris in teinperate ecosystems. Adv. Ecol. Res., 15: 133-302.

JACKSON. P.D., 1978. Spawning and early deveiopinent of the river blackfish, Gadopsis marmoratus Richardson (Gadopsiformcs: Gadopsidae), in the McKenzie River, Victoria. Aust. J. Mar. Freshwat. Res., 29: 293-298.

LANGFORD, T.E., 1996. Ecological aspects of New Forest streams draining one of Britain's unique areas. Freshwater Forum, 6:2-38.

MAHON, R. 1980. Accuracy of catch-effort methods for estimating fish density and biomass in ctreanic. Envir. Biol. Fishes, 5(4): 343-363

MAITLAND, P.S. \& R.N. CAMPBELL. 1992. Freshwater fishes of the British Isles. The New Naturalist Series. HarperCollins. London.

MANN, R.H.K. \& D.R. ORR, 1969. A preliminary study of the feeding relationships of fish in a hard-water and soft-water 
stream in Southern England. J. Fish. Biol., 1: 31-44.

O' CONNOR, N.A., 1992. Quantification of submerged wood in a lowland Australian stream cystem. Freshwat. Biol., 27: 387-395.

SEBER, G.A.F.,\& E.D. LE CREN, 1967. Estimating population parameters from catches large relative to the population. J. Anim. Ecol. 36: 631-643
TUBBS, C.R., 1968. The New Forest. An ecological history David Charles, Newton Abbot.

TUBBS, C.R.. 1986. The New Forest. The New Naturalist Series. Collins, London. 